\title{
Interphalangeal arthrodesis using an intramedullary nitinol implant: a prospective study
}

\author{
Intramedüller bir nitinol implant kullanarak interfalangeal artrodez: \\ Prospektif bir çalışma
}

\author{
Markus Jakubek, MD, Martin Enzendorfer, MD, Rainer Fiala, MD, Klemens Trieb, MD \\ Department of Orthopaedics and Traumatology, Klinikum Wels-Grieskirchen, Austria
}

\begin{abstract}
Objectives: This study aims to evaluate the nitinol (X-Fuse $\left.{ }^{\circledR}\right)$ implant in arthrodesis of the distal interphalangeal and the thumb joints with respect to bone fusion and clinical efficiency.

Patients and methods: This prospective study included 24 consecutive patients ( 7 males, 17 females; mean age 56.8 years; range 27 to 79 years) with nitinol $\left(\mathrm{X}-\mathrm{Fuse}^{\circledR}\right.$ ) implants in their 41 joints. All patients were followed-up clinically and radiographically with respect to fusion, complications and outcome at a minimum of 14 months postoperatively (mean $28 \pm 6$ months). X-rays, Disabilities of the Arm, Shoulder and Hand, and visual analog scale scores were recorded preoperatively and at postoperative fifth week, third month, first year, and subsequent visits.
\end{abstract}

Results: The Disabilities of the Arm, Shoulder and Hand score improved significantly from preoperative 37.7 points to postoperative 14.5 points at first year. The visual analog scale score improved significantly from preoperative 5.5 to postoperative 0.85 points at first year. Failure to fuse only occurred in two joints $(5 \%)$, resulting in fusion after reoperation. No other severe complications such as deep infection, intraoperative fracture, wound healing problems or regional dystrophy were observed.

Conclusion: The X-Fuse ${ }^{\circledR}$ implant may be a reliable alternative method for finger joint arthrodesis.

Keywords: Arthrodesis; interphalangeal; intramedullary; nitinol; X-Fuse ${ }^{\circledR}$.

Arthrodesis of the distal interphalangeal (DIP) joint and the interphalangeal (IP) joint of the thumb is widely acknowledged as an indicated treatment for traumatic, inflammatory and primary osteoarthritis of these respective joints. There is a variety of
$\ddot{Z z}$

Amaç: $\mathrm{Bu}$ çalışmada distal interfalangeal ve başparmak eklemlerinin artrodezinde nitinol (X-Fuse ${ }^{\circledR}$ ) implant, kemik füzyonu ve klinik etkinlik açısından değerlendirildi.

Hastalar ve yöntemler: $\mathrm{Bu}$ prospektif çalışmaya 41 ekleminde nitinol (X-Fuse ${ }^{\circledR}$ implant olan 24 ardışık hasta (7 erkek, 17 kadın; ort. yaş 56,8 yıl; dağılım 27-79 yıl) dahil edildi. Tüm hastalar ameliyat sonrası en az 14 ay (ort. $28 \pm 6$ ay) füzyon, komplikasyonlar ve sonuçlar açısından klinik ve radyografik olarak takip edildi. Röntgen filmleri, Kol, Omuz ve El Sorunları ve görsel analog ölçeği skorları ameliyat öncesinde ve ameliyat sonrası beşinci hafta, üçüncü ay, birinci yıl ve sonraki vizitlerde kaydedildi.

Bulgular: Kol, Omuz ve El Sorunları skoru ameliyat öncesi 37,7 puandan ameliyat sonrası birinci yılda 14,5 puana anlamlı şekilde iyileşti. Görsel analog ölçeği skoru ameliyat öncesi 5,5 puandan ameliyat sonrası birinci yılda 0,85 puana anlamlı şekilde iyilești. Sadece iki eklemde (\%5) füzyon gerçekleşmedi; yeniden ameliyatı takiben füzyon oldu. Derin enfeksiyon, ameliyat sırası kırık, yara iyileşmesi sorunları veya bölgesel distrofi gibi diğer ciddi komplikasyonlar gözlemlenmedi.

Sonuç: X-Fuse ${ }^{\circledR}$ implant parmak eklemi artrodezinde güvenilir bir alternatif yöntem olabilir.

Anahtar sözcükler: Artrodez; interfalangeal; intramedüller; nitinol; X-Fuse ${ }^{\circledR}$.

accepted methods of fixation. It is possible to perform an osseous fusion with Kirschner wires (K-wires) in a crossed technique or tension band technique. ${ }^{[1]}$ The use of headless compression screws, either cannulated or uncannulated, is the most common technique. ${ }^{[2]}$

- Received: October 13, 2016 Accepted: March 06, 2017

- Correspondence: Prof. Klemens Trieb, MD. Department of Orthopaedics Klinikum Wels-Grieskirchen, Grieskirchnerstr. 42, 4600 Wels, Austria. Tel: +43724241592308 e-mail: Klemens.trieb@klinikum-wegr.at 
For the surgical method using a headless compression screw, a wide range of union rates have been reported in the literature, ranging from $80 \%$ up to $100 \%$. ${ }^{[3]}$ Other possibilities are the use of a bioabsorbable implant (poly-L-lactide rod) as an intramedullary nail, ${ }^{[4]}$ or to perform a plate fixation. ${ }^{[5]}$ Although entire fixation of the respective joint mostly releases painful symptoms, functional procedures such as the pinching grip are difficult to perform. Since 2008, a new intramedullary elastic implant is available. This nitinol (X-Fuse ${ }^{\circledR}$ Stryker GmbH, Selzach, Switzerland) implant was developed for the IP joint of the thumb, and proximal IP joint arthrodesis of the hand. It is a metal alloy of nickel and titanium, where these two elements are present in roughly equal atomic percentages. Nitinol alloys exhibit two closely related and unique properties: shape memory and superelasticity, allowing $0^{\circ}-25^{\circ}$ of flexion of the operated joint for improved functional capabilities. Furthermore, four different sizes are available for optimal fit within the finger joint. Studies reporting its outcome are scarce, not prospective and with rather small patient groups. ${ }^{[6-8]}$ Therefore, in this study, we aimed to evaluate the nitinol $\left(\mathrm{X}\right.$-Fuse $\left.{ }^{\circledR}\right)$ implant in arthrodesis of the distal IP and the thumb joints with respect to bone fusion and clinical efficiency.

\section{PATIENTS AND METHODS}

This prospective study included 24 consecutive patients ( 7 males, 17 females; mean age 56.8 years; range 27 to 79 years) with 41 nitinol (X-Fuse ${ }^{\circledR}$ ) implants of DIP and IP joints of the hand. The study was conducted between 2009 and 2012 at Klinikum WelsGrieskirchen. Inclusion criteria were patients aged $>20$ years, with primary osteoarthritis, inflammatory arthritis or posttraumatic disorders of the IP or DIP joints of the hand. Exclusion criteria were age lower than 20 years, diabetes, current pregnancy, local or generalized infection, and previous allergic reactions to nickel. Of the 41 implants, $80 \% \quad(n=33)$ were operated due to primary osteoarthritis, $7 \%$ $(n=3)$ due to inflammatory arthritis, $7 \% \quad(n=3)$ due to posttraumatic disorders, as well as congenital deformity $(\mathrm{n}=1)$ and after a failed screw arthrodesis $(n=1)$. The study protocol was approved by the Hospital Ethics Committee. A written informed consent was obtained from each patient. The study was conducted in accordance with the principles of the Declaration of Helsinki.

All operations were performed under general or plexus anesthesia. A tourniquet has been used for all patients. Preoperatively and at follow-up visits, all patients were investigated using X-ray imaging, the Disability of the Arm, Shoulder and Hand (DASH) outcome ${ }^{[9]}$ and visual analog scale (VAS) for pain. ${ }^{[10]}$ Values were recorded pre-, intraoperatively, immediately postoperatively, and at postoperative fifth week, third month, first year and subsequent follow-ups.

The DASH outcome is a self-report questionnaire with 30 items to monitor physical function and symptoms of people with upper limb disorders over time. It is scored from 0 to 100 , where a lower score indicates better functioning. The VAS for pain is a selfrecorded measure to reflect the current intensity of pain in whole numbers from 0 to 10 , where 0 indicates no pain whatsoever. Within the investigation of patient satisfaction using DASH and VAS, we did not feel the need to statistically compare the differences of individual clinical scales, as the simple trend of amelioration of pain and improvements in activities of daily living within our small group of patients were meant to be seen indicatory. All intra- and postoperative complications were documented at a minimum follow-up of 14 months (mean $28 \pm 6$ months). The surgical technique was standardized starting with a transverse incision on the dorsal side of the DIP or IP joint with sectioning of the extensor tendon. A resection of the articular osteophytes was performed, and the proximal and distal articular surfaces were opened using a $2 \mathrm{~mm}$ drill and burr. Next, the appropriate rasps were used to widen the intramedullary canal proximally and distally. After the insertion of the trial implant, the correct positioning was approved using intraoperative X-ray imaging in anteroposterior (AP) and lateral views. Then, the original implant (Figures 1-3) was inserted. The implant is available in four different sizes and three different angle options $\left(0^{\circ}, 15^{\circ}, 25^{\circ}\right)$. The original implant was inserted under manual compression, then followed by a final intraoperative assessment using X-ray imaging (AP and lateral). The wound was closed utilizing a 4-0 prolene suture, and a sterile dressing was placed in conjunction with a plaster splint. After 10 days, the sutures were removed and a short custom-made plaster splint was applied for an immobilization period of five weeks postoperatively.

\section{RESULTS}

Of the 41 fused joints, nine were thumb IP joints, the remaining 32 were DIP joints, with 11 index fingers, seven middle fingers, six ring fingers and eight small fingers receiving surgical treatment. Nine implants with a flexion angle of $25^{\circ}$ have been used for the nine IP arthrodeses of the thumb. For the arthrodesis of the distal IP joint, 19 implants with a flexion angle 


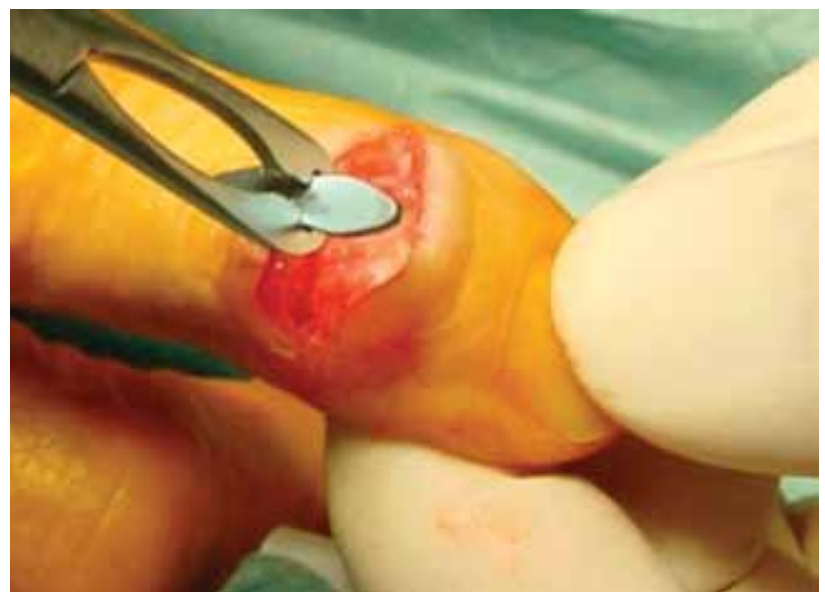

Figure 1. Intraoperative picture of trial X-fuse ${ }^{\circledR}$ implant.

of $15^{\circ}$, and 13 implants with a flexion angle of $0^{\circ}$ have been used.

The DASH score improved from a preoperative mean of 37.7 points (range 20.8-70.8 points) to a postoperative mean of 26.3 points (range 7.5-62.5 points) at third months, and a mean of 14.5 points (range 1.7-28.3 points) at first year.

The VAS for pain score improved from a preoperative mean of 5.5 points (range 1-9 points) to a postoperative mean of 2.2 points (range $0-4$ points) at third months, and a mean of 0.85 points (range 0-2 points) at first year.

For all patients, X-ray results were obtained at the previously mentioned intervals. Of the implants, $95 \% \quad(n=39)$ resulted in bony fusion within the first postoperative three months. Failure of fusion occurred only in two joints (5\%). For one of these cases, the implant was removed and a revision was undertaken using a cannulated screw and autologous cancellous bone graft. For the other case, the implant

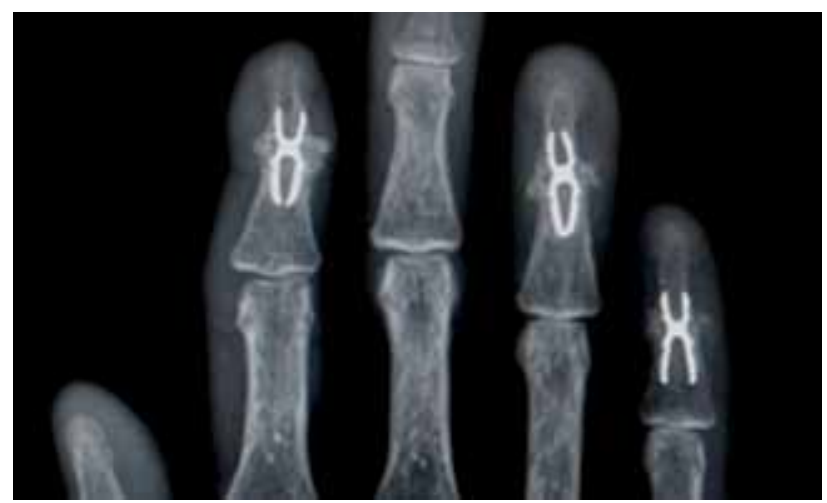

Figure 2. Postoperative X-ray six months after arthrodesis of three distal interphalangeal joints showing fusion.

was exchanged to a larger $\mathrm{X}$-Fuse ${ }^{\circledR}$ implant and an autologous cancellous bone graft was inserted. Subsequently, both cases presented bony union at the next three-month follow-up.

Three patients demonstrated mild complications other than lack of bony fusion. One patient complained of reversible paresthesia within the respective fingertip, and the other two patients complained about transient nail disorders; however, no revision surgery was required for these three cases. No severe complications such as deep infection, intraoperative fracture, wound healing problems or regional dystrophy were found. In five patients $(21 \%)$, additional independent operations of the hand had to be undertaken subsequently. Two patients had a resection arthroplasty of the trapezium, one patient had a carpometacarpal arthrodesis, one patient had a carpal tunnel release, and one patient had the removal of a giant cell tumor.

\section{DISCUSSION}

Documented union rates associated with DIP and IP joint arthrodesis of the hand vary widely in the
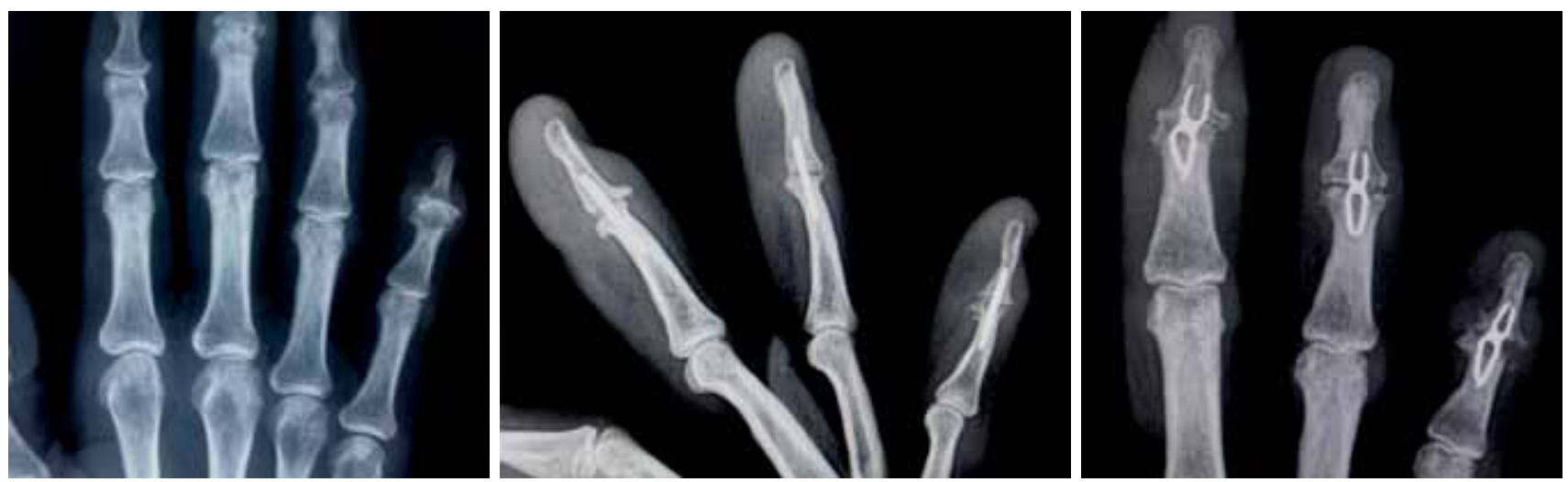

Figure 3. Pre- and postoperative X-rays after arthrodesis (anteroposterior and lateral). 
current literature. A systematic review of 32 studies (1,125 digits) analyzed the three most commonly reported techniques (K-wire, headless compression screw, cerclage wire), finding insufficient evidence to support any particular technique. ${ }^{[2]}$ Rates of union reported for generalized screw arthrodesis are ranging from $80 \%$ to $100 \%$ within three months postoperatively, ${ }^{[3]}$ showing similar results to other commonly performed techniques such as bioabsorbable rod as intramedullary nail, ${ }^{[4]}$ intramedullary K-wire fixation and interosseous wiring ${ }^{[8]}$ as well as plate and screw fixation. ${ }^{[5]}$ We were able to demonstrate a $95 \%$ primary fusion rate within the same time interval using the nitinol (X-Fuse ${ }^{\circledR}$ ) system, therefore showing effective comparable results. The other $5 \%(\mathrm{n}=2)$ achieved bony union within three months after revision surgery.

To our knowledge, this study represents the largest consecutive series of cases using the intramedullary nitinol (X-Fuse ${ }^{\circledR}$ ) implant system for interphalangeal arthrodesis of the hand. ${ }^{[11]}$ There are only three other studies dealing with the X-Fuse ${ }^{\circledR}$ implant system for DIP and IP arthrodeses of the hand..$^{[6-8]}$ Seitz and Marbella ${ }^{[6]}$ published results of a two-year follow-up of 16 patients (21 DIP arthrodeses and 11 thumb arthrodeses), observing 31 out of 32 patients (97\%) to show painless bony fusion within 10 weeks postoperatively. One patient demonstrated fibrous union with good stability and without pain, therefore no revision surgery was performed. Savvidou and Kutz ${ }^{[7]}$ demonstrated a preliminary study, treating seven patients in the IP joint and metacarpophalangeal joint of the thumb. Clinically, they could not observe any finger instability, softtissue irritation, infection, or uncommon nail morphology at any follow-up visit. Within our larger patient group, we were also able to demonstrate a lack of further complications, except for two patients with postoperative transient nail disorders and one patient with reversible paresthesia, requiring no further treatment. Ameline et al. ${ }^{[8]}$ observed a fusion rate of $94.8 \%$ (37/38) during evaluation of fusion position, finding a moderate alteration of less than $10^{\circ}$ in arthrodesis position within the immediate postoperative interval without any clinical consequence. Our 95\% rate of bony fusion (39/41) shows similar results, proving the nitinol implant to be a safe and effective technique for DIP and IP joint arthrodeses. This study, unlike the others before, utilized clinical scores to objectify patients' physical functioning and satisfaction over time. Future randomized comparative studies are required to establish superiority of a certain technique for DIP and IP joint arthrodeses of the hand.
The advantage of the nitinol (X-Fuse $\left.{ }^{\circledR}\right)$ implant is the intramedullary fixation compared to screw fixation, where screw removal as a result of symptomatic protruding hardware is required in as many as $8 \%$ of patients. ${ }^{[2,3]}$ Another advantage is provided by the availability of different flexion angles, offering a greater possibility to meet individual patients' needs during activities of daily living, especially in terms of enabling a more efficient pinching grip. ${ }^{[6,7]}$

The implant system is contraindicated in patients with previous allergic reactions to nickel. This should be kept in mind during preoperative planning, and should be considered a possible cause of nonunion after arthrodesis or particle-induced aseptic implant loosening. To our knowledge, there is no similar metal-free system available on the market. As total hip and total knee replacement systems made of ceramic are currently being developed and optimized, ${ }^{[12,13]}$ future efforts concerning metal-free intramedullary systems for interphalangeal arthrodesis might be necessary.

Similar nitinol intramedullary fixation devices are currently being utilized in IP joints of toes, showing efficient results concerning fusion and rather low rates of complication. ${ }^{[14,15]}$ Another recent study concerning hammer toe treatment using this nitinol implant within 156 toes reported a fusion rate of $83.8 \%$ after one year, where the American Orthopaedic Foot and Ankle Society's lesser metatarsophalangealinterphalangeal scale improved from 40.4 to 85.5 points, with revision surgery only being required for one case. Interestingly, the authors concluded that no need for reoperation was seen in patients with incomplete joint fusion who demonstrated a stable joint without any pain. ${ }^{[16]}$ In our study, two cases lacking bony fusion of the distal IP joint of the hand three months postoperatively underwent revision surgery to improve clinical outcome. We believe that a resulting pseudoarthrosis after nonunion of finger joints causes greater limitations and pain than within joints of toes. Therefore, revision surgery should be performed in finger joints if bony fusion of finger joints cannot be established radiologically three months postoperatively.

However, there have been a few limitations of our study. We primarily analyzed only a small number of patients at our institution within the short-term. A multicenter study with mid-term results is needed to confirm our results. Furthermore, this study was simply an observational study. Different methods of interphalangeal arthrodesis could be compared and contrasted within future efforts. 
In conclusion, the nitinol (X-Fuse ${ }^{\circledR}$ ) system is a reliable implant for the fusion of the DIP and IP joints of the hand, expressing a bony fusion rate comparable to other techniques, as well as a similarly low rate of complications. The availability of different flexion angles and sizes of this implant enables a personalized approach for patients' individual needs, offering proper radiological outcome, efficient patient satisfaction during activities of daily living, and cosmetically acceptable results. Further multicenter clinical studies with a greater number of patients are required to establish a possible superiority of this system compared to other techniques of arthrodesis.

\section{Declaration of conflicting interests}

The authors declared no conflicts of interest with respect to the authorship and/or publication of this article.

\section{Funding}

The authors received no financial support for the research and/or authorship of this article.

\section{REFERENCES}

1. Han SH, Cha YS, Song WT. Arthrodesis of distal interphalangeal joints in the hand with interosseous wiring and intramedullary K-wire fixation. Clin Orthop Surg 2014;6:401-4.

2. Dickson DR, Mehta SS, Nuttall D, Ng CY. A systematic review of distal interphalangeal joint arthrodesis. J Hand Microsurg 2014;6:74-84.

3. Kocak E, Carruthers KH, Kobus RJ. Distal interphalangeal joint arthrodesis with the Herbert headless compression screw: outcomes and complications in 64 consecutively treated joints. Hand (N Y) 2011;6:56-9.

4. Arata J, Ishikawa K, Soeda H, Kitayama T. Arthrodesis of the distal interphalangeal joint using a bioabsorbable rod as an intramedullary nail. Scand J Plast Reconstr Surg Hand Surg 2003;37:228-31.

5. Mantovani G, Fukushima WY, Cho AB, Aita MA, Lino W Jr, Faria FN. Alternative to the distal interphalangeal joint arthrodesis: lateral approach and plate fixation.
J Hand Surg Am 2008;33:31-4.

6. Seitz WH Jr, Marbella ME. Distal interphalangeal joint arthrodesis using nitinol intramedullary fixation implants: X-fuse implants for DIP arthrodesis. Tech Hand Up Extrem Surg 2013;17:169-72.

7. Savvidou C, Kutz J. Interphalangeal and thumb metacarpophalangeal arthrodesis with an intramedullary implant. Ann Plast Surg 2013;70:34-7.

8. Ameline $\mathrm{T}$, Bégot $\mathrm{V}$, Ardouin L, Hulet $\mathrm{C}$, Hanouz N. Arthrodesis of thumb interphalangeal and finger distal interphalangeal joints using the intramedullary X-Fuse(®) implant: Retrospective analysis of 38 cases. Chir Main 2015;34:67-72.

9. Hudak PL, Amadio PC, Bombardier C. Development of an upper extremity outcome measure: the DASH (disabilities of the arm, shoulder and hand) [corrected]. The Upper Extremity Collaborative Group (UECG). Am J Ind Med 1996;29:602-8.

10. Bijur PE, Silver W, Gallagher EJ. Reliability of the visual analog scale for measurement of acute pain. Acad Emerg Med 2001;8:1153-7.

11. Atik OŞ. Are all case reports worth publishing? Eklem Hastalik Cerrahisi 2016;27:61.

12. Meier E, Gelse K, Trieb K, Pachowsky M, Hennig FF, Mauerer A. First clinical study of a novel complete metalfree ceramic total knee replacement system. J Orthop Surg Res 2016;11:21.

13. Nieuwenhuijse MJ, Nelissen RG, Schoones JW, Sedrakyan A. Appraisal of evidence base for introduction of new implants in hip and knee replacement: a systematic review of five widely used device technologies. BMJ 2014;349:5133.

14. Sandhu JS, DeCarbo WT, Hofbauer MH. Digital arthrodesis with a one-piece memory nitinol intramedullary fixation device: a retrospective review. Foot Ankle Spec 2013;6:364-6.

15. Roukis TS. A 1-piece shape-metal nitinol intramedullary internal fixation device for arthrodesis of the proximal interphalangeal joint in neuropathic patients with diabetes. Foot Ankle Spec 2009;2:130-4.

16. Coillard JY, Petri GJ, van Damme G, Deprez P, Laffenêtre O. Stabilization of proximal interphalangeal joint in lesser toe deformities with an angulated intramedullary implant. Foot Ankle Int 2014;35:401-7. 